\title{
Adaptive contents distribution based on traffic congestion on digital signage system
}

\author{
Ridhwan Alifudin ${ }^{* 1}$, Andrian Rakhmatsyah ${ }^{2}$, Rahmat Yasirandi ${ }^{3}$ \\ Telkom University, Indonesia ${ }^{1,2,3}$
}

\author{
Article Info \\ Keywords: \\ Digital Signage, Ad Content, Adaptive \\ Content, Audience \\ Article history: \\ Received: 15 April 2019 \\ Revised: 4 July 2019 \\ Accepted: 23 July 2019 \\ Available Online 30 July 2019

\section{Cite:} \\ Alifudin, R., Rakhmatsyah, A., \& Yasirandi, R. \\ (2019). Adaptive Contents Distribution Based \\ on Traffic Congestion on Digital Signage \\ System. Kinetik: Game Technology, \\ Information System, Computer Network, \\ Computing, Electronics, and Control, 4(3) \\ doi:http://dx.doi.org/10.22219/kinetik.v4i3.810 \\ * Corresponding author. \\ Ridhwan Alifudin \\ E-mail address: \\ ridhwan@student.telkomuniversity.ac.id
}

\begin{abstract}
Current technological developments have been very rapid. One of them is the many choices of technology and media to deliver information to the public. Digital Signage is one of the most popular information delivery systems today, displays on digital or electronic media, and it can convey new details. The information usually showed in the form of advertising content in the format of images or videos. Ad content displayed is static, meaning that the ad content will be display in the order specified. This system usually placed next to a broad road. A place that is considered to have a broad audience and requires a significant amount of money to display ad content. However, this causes ad content owners who do not have enough costs not to be able to show the ad content in a particular place. Therefore, this research makes the content management system adaptive to road congestion situations which represented as audience quantities so that the costs can be adjusted. Data is obtained from the Google Maps API and analyzed the traffic congestion by conducting experiments. The compatibility between density and content after testing the results in $100 \%$ accuracy.
\end{abstract}

\section{Introduction}

Advertising has an essential role in the present. Advertising has become a necessity for all circles, both for customers, producers, and traders [1]. Advertising is content that has a message to convey to the audience. Ad content disseminated through media such as billboards. This media is useful for disseminating information on products or services to consumers [2]. One of the leading advertising media lately is Digital Signage (DS) [3]. DS is a digital media that displays different information content and advertising content visually in the form of images, videos or moving text and is displayed using electronic media such as LCD TV or digital billboards [4]. DS is a digital media that displays various information content and advertising content visually. Its strengths are more attractive than others [5], [6]. This media can view more than one ad content that changes continuously [6], [7]. Besides, DS is also easily accessed by other digital devices such as cellular phones and computers [8], [9]. These indicate that DS can reduce the shortcomings of conventional information boards [10].

DS takes over in the indoor and outdoor environments quickly and displays various content, including advertising content [11]. DS usually placed next to significant crossroads, shopping centers, school, airport, and offices. For fixed DS placement locations, generally using a large monitor and combined with a computer [12]. In addition to the major road intersections, one of the strategic locations is because many people are passing by using vehicles. However, this strategic place is relatively more expensive because it has many audiences who see advertising content. So, the problems are:

1. Ad content owners who do not have enough costs, cannot place ad content in a strategic place.

2. There is no proper content management [13].

This research analyzes and implements DS to distribute content adaptively. Ad content can change according to the number of audiences passing by at a significant crossroads by seeing the congestion of traffic so that costs can adjust to the number of viewers. Content owners who spend a considerable amount of money to display their content will prioritize when the situation at a significant crossroads was known crowded.

\section{Research Method}

In Chapter 1, an analysis of the problems in the Digital Signage (DS) system is done and looks for a solution. In chapter 2.1, understand the existing DS architecture. After understanding the architecture, identify traffic congestion by retrieving data from the Google Maps API described in chapter 2.2.

Cite: Alifudin, R., Rakhmatsyah, A., \& Yasirandi, R. (2019). Adaptive Contents Distribution Based on Traffic Congestion on Digital Signage System. Kinetik: Game Technology, Information System, Computer Network, Computing, Electronics, and Control, 4(3). doi:http://dx.doi.org/10.22219/kinetik.v4i3.810 


\subsection{Digital Signage (DS)}

DS is a digital-based information service to convey information visually and attractively [5], [6]. The content displayed can be more than one content. Content that usually contains about this advertisement will be displayed in sequence in the order specified. The DS system consists of clients, servers, and networks. Figure 1 is a DS architecture that describes the relationship between components and parts of each component [13].

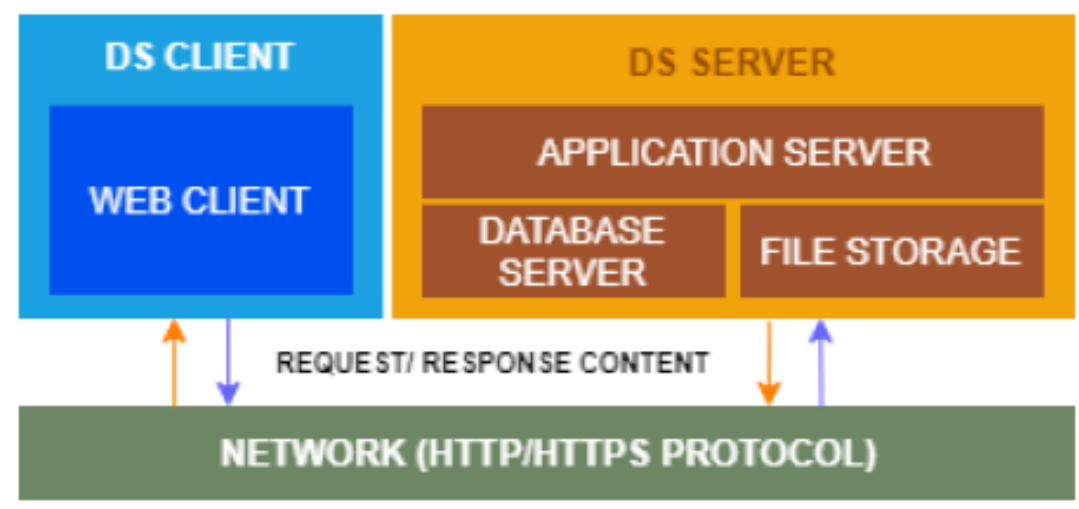

Figure 1. Digital Signage Architecture [13]

The system has three components, namely server, client, and network. Each element has its function. The server functions to manage and store content consisting of application servers, database servers, and file storage. The client serves to display the content provided by the server. The network function is distributing content from the server to clients. Table 1 explains in more detail the DS components.

Table 1. Components of the Digital Signage System

\begin{tabular}{|c|c|c|}
\hline \multicolumn{2}{|c|}{ Components } & Description \\
\hline & Application Server & Manage content \\
\hline DS server & Database Server & Save content information \\
\hline & File Storage & Save content data \\
\hline DS Client & Web Client & Displa) \\
\hline Network & HTTP/HTTPS & $\begin{array}{c}\text { Distribute the content provided by the server to the } \\
\text { client }\end{array}$ \\
\hline
\end{tabular}

Various applications that have been developed to support DS technology. XIBO is one of them [9], [14]. Besides, using web applications can also support DS technology. The tools needed to develop web-based DS are node.js, JavaScript, HTML5, CSS, MySQL and PHP [15], [16]. Web-based applications are suitable because they can easily manage content and support marketing activities [17]. Most applications that support DS technology consist of clients and servers and are connected via the internet [18].

\subsection{Congestion Identification}

Find out a full location, a particular function or function is needed. The congestion of vehicles is showing a busy place at a massive crossroads. Google Maps API is a map service that allows users to receive various information provided such as traffic situation, the distance between two locations and travel time between a site and another location [1], [19], [20]. This condition makes it easier for developers because they do not need to create maps and information.

Application Programming Interface (API) is a set of service functions that can be executed and received by external program entities [21]. The traffic information contained in the Google Maps API is very much; for example, travel time information between two different locations. There are two functions to find out information about travel time or two different places. First is the function "duration" this function will return the travel time to travel the route and expressed in units of seconds. The second is the function "duration in traffic", this function will return the travel time between two different locations in units of seconds, taking into account the current and historical traffic conditions [19].

If the current travel time exceeds the regular travel time, then the traffic conditions are dense, and the color on the track is red, as shown in Figure 2. If the current travel time is less than the regular travel time, the traffic conditions are low, and the color in the path is blue. If the travel time is the same or not too large the difference in time with regular time, then the traffic conditions are not quiet and not congested (medium) and the color on the track is orange. 


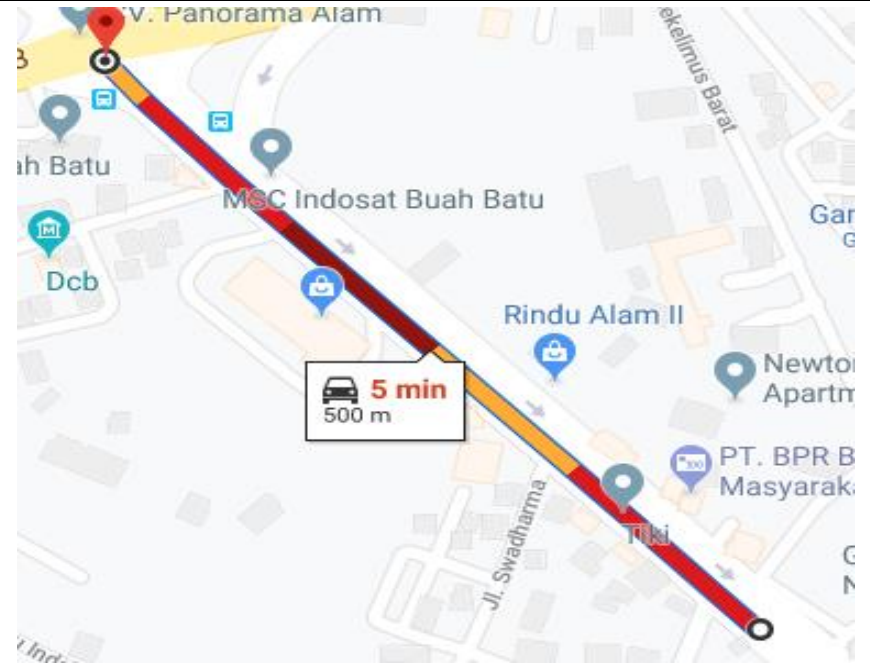

Figure 2. Examples of Traffic Congestion Conditions

\section{Results and Discussion}

\subsection{System Overview}

Content uploaded to the server via the internet. Every monitor display contents. The monitor is placed next to a large road junction and will connect to a server via the internet. The server sends the Content presented to the web. The web receives congestion information from the Google Maps API and schedules the content displayed on the monitor as shown in Figure 3.

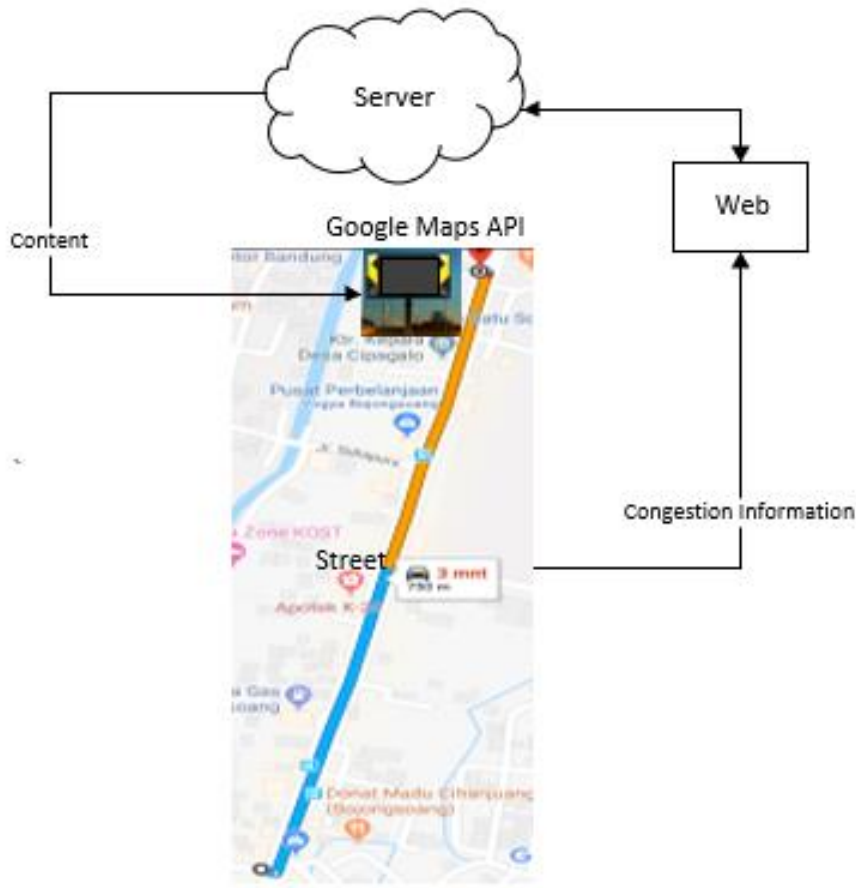

Figure 3. System Overview

\subsection{System Flow}

Traffic congestion information obtained from Google Maps by utilizing the Google Maps API using two functions, namely the function "duration" and the function "duration_in_traffic". The output obtained from the function "duration" is the travel time between two different locations while the function "duration in traffic" spends travel time taking into account the current traffic congestion. After that, the data is analyzed whether the traffic is congested or not, by comparing the output of the "duration" function with the function "duration_in_traffic. Furthermore, the content will be scheduled and arranged according to the traffic congestion conditions. The content contained in the system distributed and displayed on the monitor. The flow of the DS system as shown in Figure 4.

Cite: Alifudin, R., Rakhmatsyah, A., \& Yasirandi, R. (2019). Adaptive Contents Distribution Based on Traffic Congestion on Digital Signage System. Kinetik: Game Technology, Information System, Computer Network, Computing, Electronics, and Control, 4(3). doi:http://dx.doi.org/10.22219/kinetik.v4i3.810 
Take traffic congestion data

Analysis
traffic
congestion

Content

scheduling
Content

distribution
Show

content

Figure 4. Flow of the Digital Signage System

\subsection{Content Scheduling}

In this research, Content was designed to be three classes to be scheduled based on traffic congestion. If traffic that monitored is congested, the Content that will be displayed is the class A content. If the traffic monitored (not congested and not quiet), then the Content that will be displayed is class B Content. If the traffic that monitored is quiet, the Content that displayed is class $\mathrm{C}$ Content.

To determine the traffic congestion class (congested, medium, quiet) uses color on the path around the monitor (displaying Content) found on Google Maps. If the color of the track is red, then the traffic conditions are congested. If the color of the path is blue, the traffic conditions are quiet. If the color of the track is orange, the traffic conditions are moderate. Under certain conditions, the colors on the path around the monitor can consist of three colors, namely red, orange, and blue. These require analysis to determine traffic congestion. In this research, experiments were carried out in three places, namely around the traffic light Buah Batu (Buah Batu Street, Bandung City), around Transmart Buah Batu (Terusan Buah Batu Street, Bandung District) and the traffic lights on Soekarno-Hatta. These three places, jams often occur at specific times periodically.

DS system calculates the travel time using the function "duration" and "duration_in_traffic" from the Google Maps API. The distance used is 500 meters from the monitor placed and chosen because human visibility is limited, and with a range of 500 meters can still see the monitor screen on the DS system (Videotron). Experiments were conducted based on data from the google fire map to find out the congestion of traffic. Data were analyzed and produced traffic density categories in Table 2.

Table 2. Congestion Analysis

\begin{tabular}{cccc}
\hline duration(s) & duration_in_traffic $(s)$ & Color & Congestion \\
\hline 115 & 110 & $70 \%$ blue & Quiet \\
115 & 128 & $50 \%$ orange & Medium \\
115 & 146 & $50 \%$ red & Congested \\
\hline
\end{tabular}

Table 2 explains that if the duration is higher than duration_in_traffic, the traffic congestion condition is quiet. If the duration +30 is smaller than duration_in_taffic, then the congestion of traffic conditions is congested and if the duration is shorter than duration_in_traffic and duration +30 is higher than duration_in_traffic then medium traffic congestion.

The DS client for implementing DS system uses 3 (three) monitors in different regions. The duration of each content displayed is 30 seconds. The amount of content presented is three content per class. The monitor will display all content in a class based on the latest traffic congestion data. Content queues are sorted using the FIFO (First In First Out) queue. That is the content that first enters the system will be displayed first. After all the content in one class has been presented, the system will retrieve the latest traffic congestion data and display all content in a class based on its congestion.

\subsection{Testing}

This test to ensure that the content displayed is following with the congestion of traffic. Testing is done using two computer monitors to display content. The content displayed is compared to content according to congestion conditions around the monitor by using a monitor to show content and compare it with traffic conditions at that time. Testing is carried out for two days, 5 hours on the first day $(11: 00-16: 00)$ and 1 hour on the second day (20:00 - 21:00).

In two days, testing was carried out in three regions, namely the first day of traffic congestion conditions in three common and reliable monitored areas (Google Maps). The content displayed is class A and class B, according to the traffic congestion conditions. On the second day, the traffic congestion conditions are quiet (Google Maps), and the content displayed is class $\mathrm{C}$ content. Table 3 shows the results of testing in three different regions, nine results of testing data obtained.

Table 3. Results

\begin{tabular}{ccc}
\hline Regions & Google Maps & DS Client \\
\hline \multirow{2}{*}{ Around Traffic Light Buah Batu } & Blue & C Content \\
& Orange & B Content \\
& Red & A Content \\
\hline
\end{tabular}

(c) 2019 The Authors. Published by Universitas Muhammadiyah Malang

This is an open access article under the CC BY SA license. (https://creativecommons.org/licenses/by-sa/4.0/) 


\begin{tabular}{ccc}
\hline \multirow{2}{*}{ Around Transmart Buah Batu } & Blue & C Content \\
& Orange & B Content \\
& Red & A Content \\
& Blue & C Content \\
Around Traffic Light Soekarno Hatta & Orange & B Content \\
& Red & A Content \\
\hline
\end{tabular}

Around the traffic light Buah Batu, when traffic condition is quiet and marked with blue track, the content displayed is class $\mathrm{C}$ content. When the traffic condition is medium marked with orange track, the content displayed is class $\mathrm{B}$ content. When traffic conditions are congested and marked with red track, the content displayed is class A content. This shows that the content displayed is in accordance with the congestion conditions of the traffic around the monitor that displays the content. Around the Transmart Buah Batu and around the traffic light Soekarno Hatta also displays content that matches the congestion of traffic.

These nine-test data (Table 3 ) get results that match the congestion of traffic with the ad content displayed. When traffic conditions are quiet, the content displayed is class $\mathrm{C}$ content. During moderate traffic conditions, the content displayed is class B content. During heavy traffic conditions, the content displayed is class A content. When content changes occur, there was a delay but still within reasonable limits. The accuracy obtained in this case is $100 \%$. This result proves that DS systems that display content adaptively based on traffic congestion, help content owners or traders who have limited funds by adjusting costs based on traffic congestion.

\section{Conclusion}

This system is running well, and it can be seen from the results of the test in chapter 3 that the results match between the congestion of traffic with the ad content displayed. Nine data were obtained (Table 3) and all data showed a match between the congestion of traffic and ad content displayed so as to produce $100 \%$ accuracy. Based on these results, it can be concluded that the construction of a DS system that pays attention to traffic conditions and advertising content divided into three classes $(A, B$, and $C)$ is expected to help content owners who have limited funds. Funds can be adjusted to traffic congestion conditions around the digital billboard (DS Client). The Google Maps API can also be used to retrieve traffic density conditions in real-time.

If this system is to be built, use high-speed internet because the content displayed is video. The amount of ad content will be displayed is adjusted to the density around where the ad content is displayed. This recommendation can be further investigated in the future research.

\section{References}

[1] T. Ajnawala, R. Pujari, A. Shaikh, and B. Jaybhaye, "Embedded System for Dynamic Location-Based Advertisement using Google Maps API," in International Research Journal of Engineering and Technology (IRJET), Vol. 04, No. 04, Pp. 2375-2379, 2017.

[2] R. F. Rahmat and O. S. Sitompul, "Advertisement billboard detection and geotagging system with inductive transfer learning in deep convolutional neural network," TELKOMNIKA, Vol. 17, No. 5, Pp. 2659-2666, 2019, doi: 10.12928/TELKOMNIKA.v17i5.11276. http://dx.doi.org/10.12928/telkomnika.v17i5.11276

[3] K. Yu, C. Yu, B. Yeh, C. Hsu, and H. Hsieh, "The Design and Implementation of a Mobile Location-Aware Digital Signage System," in Sixth International Conference on Mobile Ad-hoc and Sensor Networks, No. 4, Pp. 235-238, 2010, doi: 10.1109/MSN.2010.44. https://doi.org/10.1109/MSN.2010.44

[4] I. W. A. Suranata and I. N. K. Wardana, "Digital Signage sebagai Media Penyampaian Informasi Kegiatan Akademik Berbasis Mikrokomputer," Creat. Inf. Technol. J., Vol. 1, No. 4, Pp. 306, Apr. 2014, doi: 10.24076/citec.2014v1i4.30. https://doi.org/10.24076/citec.2014v1i4.30

[5] R. Panuntun, A. F. Rochim, and K. T. Martono "Perancangan Papan Informasi Digital Berbasis Web pada Raspberry Pi," J. Teknol. dan Sist. Komput., Vol. 3, No. 2, Pp. 192-197, 2015, doi: 10.14710/jtsiskom.3.2.2015.192-197. https://doi.org/10.14710/jtsiskom.3.2.2015.192-197

[6] J. Scaeffler, Digital Signage Sofware, Network, Advertising, and Displays: A Primer for Understanding the Business. Burlington, MA 01803, USA: Elsevier, 2008.

[7] C. Bauer, P. Dohmen, and C. Strauss, "Interactive Digital Signage - An Innovative Service and Its Future Strategies," in International Conference on Emerging Intelligent Data and Web Technologies, No. 11, Pp. 137-142, 2011, doi: 10.1109/EIDWT.2011.29. https://doi.org/10.1109/EIDWT.2011.29

[8] M. Huh, W. Hyun, S. Kim, and S. Kang, "Design of Disaster Alerting Functionality for Digital Signage Service," in International Conference on Advanced Communication Technology, Pp. 618-621, 2014, doi: 10.1109/ICACT.2014.6779035. https://doi.org/10.1109/ICACT.2014.6779035

[9] J. Khan, S. Khusro, and F. Jabeen, "Digital Signage Systems: Past , Present and Future," in International Conference on Computer Science \& Computational Mathematics, Pp. 196-208, 2014.

[10] A. Mulyana and M. Aria, "Perancangan Digital Signage Sebagai Papan Informasi Digital," Majalah IImiah UNIKOM, Vol. 13, No. 2, Pp. 111118,2015

[11] R. Slawsky, Digital Display Technology: An Introduction to Digital Signage. Louisville, KY 40223, USA: Networld Media Group, 2015.

[12] Yoon, C., Lee, H., Jeon, S. H., \& Lee, H. (2011, September). Mobile digital signage system based on service delivery platform location based targeted advertisement service. In ICTC 2011 (pp. 582-586). IEEE. https://doi.org/10.1109/ICTC.2011.6082669

[13] R. Yasirandi, A. Rakhmatsyah, and R. Alifudin, "Perancangan Arsitektur Sistem Digital Signage secara Terpusat pada Negara Berkembang," Techno.Com, Vol. 18, No. 2, Pp. 145-153, May 2019, doi: 10.33633/tc.v18i2.2304

[14] K. U. Ariawan, "Unjuk Kerja Aplikasi Digital Signage Xibo Pada Proses Pembuatan Papan Pengumuman Digital Di Jurusan Teknik Elektro," JPTK, UNDIKSHA, Vol. 13, No. 1, Pp. 50-60, 2016, doi: 10.23887/jptk-undiksha.v13i1.6846. http://dx.doi.org/10.23887/jptkundiksha.v13i1.6846

Cite: Alifudin, R., Rakhmatsyah, A., \& Yasirandi, R. (2019). Adaptive Contents Distribution Based on Traffic Congestion on Digital Signage System. Kinetik: Game Technology, Information System, Computer Network, Computing, Electronics, and Control, 4(3). doi:http://dx.doi.org/10.22219/kinetik.v4i3.810 
[15] T. Arsan, A. Parkan, and H. Konu, "Design and Implementation of Remotely Managed Embedded Digital Signage System," in International Journal of Computer Science, Engineering and Applications (IJCSEA), No. 3, 2014, doi: 10.5121/ijcsea.2014.4301.

[16] S. Alase and V. Chinchur, "IoT Based Digital Signage Board Using Raspberry PI 3," in International Research Journal of Engineering and Technology, Vol. 04, No. 05, Pp. 310-313, 2017.

[17] S. H. Prayoga and I. D. Sensuse, "Analisis Usability Pada Aplikasi Berbasis Web Dengan Mengadopsi Model Kepuasan Pengguna (User Satisfaction)," J. Sist. Inf. MTI-UI, Vol. 6, No. 1, Pp. 64-73, 2013, https://doi.org/10.21609/jsi.v6i1.278.

[18] Y. Bandung, Y. F. Hendra, and L. B. Subekti, "Design and Implementation of Digital Signage System based on Raspberry Pi 2 for e-Tourism in Indonesia," in Conference on Information Technology Systems and Innovation, 2015. https://doi.org/10.1109/ICITSI.2015.7437699

[19] Google Maps Platform, "Developer Guide | Directions API | Google Developers," 2018.

[20] O. A. Ibrahim and K. J. Mohsen, "Design and Implementation an Online Location Based Services Using Google Maps for Android Mobile," in International Journal of Computer Networks and Communications Security, Vol. 2, No. 3, Pp. 113-118, 2014.

[21] D. R. Utari and A. Wibowo, "Pemanfaatan Google Maps dalam Pembuatan Aplikasi Pemantau Kondisi Jalan dan Lalu lintas," in Seminar Nasional Teknologi Informasi \& Komunikasi, No. 1, 2013. 